Original Research Paper

\title{
Community of Mangrove Category Tree and Sapling in The Sekotong Bay, West Lombok
}

\author{
Lalu Japa $^{1^{*}}, \operatorname{Karnan}^{1} \&$ Didik Santoso ${ }^{1}$ \\ ${ }^{1}$ Biology Education Study Program, Faculty of Teacher Training and Education University of Mataram, \\ Indonesia
}

\author{
Article History \\ Received : May $02^{\text {th }}, 2021$ \\ Revised : May $15^{\text {th }}, 2021$ \\ Accepted : June 10 ${ }^{\text {th }}, 2021$ \\ Published : June $18^{\text {th }}, 2021$ \\ *Corresponding Author: \\ Lalu Japa, \\ Biology Education Study \\ Program, Faculty of Teacher \\ Training and Education \\ University of Mataram, \\ Mataram Indonesia; \\ Email: 1japa@unram.ac.id
}

\begin{abstract}
Community of mangrove in the Bay of Sekotong, West Lombok was studied to know the species composition, individual density of each species, and percentage covering of mangrove canopy. Total 28 plots of 10 $\mathrm{m} \times 10 \mathrm{~m}$ were set in 9 transects in 5 stations. Photographs of canopy covering and mangrove community composition were analyzed by using software ImageJ and template spreadsheet 10x10, the new version of March 2018. The community of mangrove of Sekotong bay, West Lombok consists of 8 species, 5 genera, and 4 families. Rhizophora apiculata \& Rhizophora stylosa were recorded in seven of nine transects ( $78 \%$ of transect). Ceriops tagal was a species that was also recorded to have the highest density (3700 trees/ha) in transect SKTM02B. The average density of the mangrove sapling category was higher than the mangrove tree category. The three highest covering percentages of canopi mangrove community took place in transects SKTM01A, SKTM01B, and SKTM04T.
\end{abstract}

Keywords: Density; Mangrove; Percentage covering; Sekotong bay;

Species composition.

\section{Introduction}

Mangrove ecosystems mostly are laying down along the coastal lines of tropical and subtropical areas which are dominated by the community of mangrove. Community of mangrove adapted to grow well and normal development in habitats with high salt concentration. Naturally, the potential of Indonesia mangrove ecosystem is much higher than those of Australia and Brazil of mangrove areas (Backmann, 1994, and Giri et al., 2011).

Some mangrove forests in many parts of Indonesia, however are now in uncertain condition, even in threatening condition. One example, mangrove forest of Bintan Island is very susceptible to tantrums and threatened (Saputra et al., 2016). The areas of Sekotong Bay West Lombok has wide enough potency of mangrove forest. However, many forms of the local community activities including traditional gold mining can bring some negative effects for the mangrove community. Some activities including mangrove reclamation can threaten the condition of mangrove forests (Saputra et al., 2016). For this reason therefore, the mangrove ecosystem of Sekotong Bay West Lombok needs to be survey regularly for getting a value of healthy condition and development as some policies on management of coastal areas developed continuously rapidly. Therefore, the mangrove ecosystem with no exception, mangrove ecosystem of Sekotong Bay West Lombok should be managed very well for the existence and conservation objectives.

Results of a research can be used as based of good management for the mangrove community conservation. The results of this research can be used as the basis of materials policies in every decision in relation to management of mangrove ecosystem areas, basically in the areas of Sekotong Bay, West Lombok.

\section{Materials and Methods}

\section{Time and Places}

Data collection of mangrove community was conducted during one week period $\left(2^{\text {nd }}-8^{\text {th }}\right.$ August 2019 at nine transects in five permanen station. All 
Japa, L et al. (2021). Jurnal Biologi Tropis, 21 (2): 441 - 447

DOI: http://dx.doi.org/10.29303/jbt.v21i2.2698

stations were located in the area's two villages namely: Pelangan and Batu Putih, District of

locality of station and transects of research are given in Table 1.

Sekotong, West Lombok. Name, coordinates, and

Table 1. List of name, coordinates, and locality of station and transects of sampling mangrove community in Sekotong Bay, West Lombok

\begin{tabular}{|c|c|c|c|c|}
\hline \multirow{2}{*}{ Station } & \multirow{2}{*}{ Transects } & \multicolumn{2}{|c|}{ Coordinates } & \multirow{2}{*}{ Locality } \\
\hline & & BT & $\mathbf{L S}$ & \\
\hline \multirow[t]{2}{*}{ SKTM01 } & SKTM01A & $115^{\circ} 53^{\prime} 671^{\prime \prime}$ & $08^{\circ} 45^{\prime} 584^{\prime \prime}$ & Dusun Siung, Desa Batu Putih \\
\hline & SKTM01B & $115^{\circ} 53^{\prime} 623^{\prime \prime}$ & $08^{\circ} 45^{\prime} 573^{\prime \prime}$ & Dusun Siung, Desa Batu Putih \\
\hline \multirow[t]{2}{*}{ SKTM02 } & SKTM02A & $115^{\circ} 54^{\prime} 302^{\prime \prime}$ & $08^{\circ} 46^{\prime} 291^{\prime \prime}$ & Dusun Pewaringan, Desa Batu Putih \\
\hline & SKTM02B & $115^{\circ} 54^{\prime} 289^{\prime \prime}$ & $08^{\circ} 46^{\prime} 336^{\prime \prime}$ & Dusun Pewaringan, Desa Batu Putih \\
\hline \multirow[t]{2}{*}{ SKTM03 } & SKTM03A & $115^{\circ} 55^{\prime} 692^{\prime \prime}$ & $08^{\circ} 46^{\prime} 429^{\prime \prime}$ & Dusun Selindungan, Desa Pelangan \\
\hline & SKTM03B & $115^{\circ} 55^{\prime} 770^{\prime \prime}$ & $08^{\circ} 46^{\prime} 353^{\prime \prime}$ & Dusun Selindungan, Desa Pelangan \\
\hline \multirow[t]{2}{*}{ SKTM04 } & SKTM04 & $115^{\circ} 56^{\prime} 114^{\prime \prime}$ & $08^{\circ} 46^{\prime} 171^{\prime \prime}$ & Dusun Kayu Putih, Desa Pelangan \\
\hline & SKTM04T & $115^{\circ} 56^{\prime} 086^{\prime \prime}$ & $08^{\circ} 46^{\prime} 213^{\prime \prime}$ & Dusun Kayu Putih, Desa Pelangan \\
\hline SKTM05 & SKTM05 & $115^{\circ} 52^{\prime} 148^{\prime \prime}$ & $08^{\circ} 44^{\prime} 884^{\prime \prime}$ & Dusun Labuan Poh, Desa Batu Putih \\
\hline
\end{tabular}

\section{Data Collection and Analyzed}

Data of mangrove vegetation were obtained by using some important tools, such as: camera, GPS, tailor meter, protractor, and waterproof paper, in plot atau quadrat transect (Syafei, 1990). Total of twenty eight plots (quadrates) of $10 \mathrm{~m} \times 10 \mathrm{~m}$ were laid down at nine transects in five stations. Photography hemispherical photography method was applied for data collection of Percentage covering of mangrove canopy (Dharmawan \& Pramudji, 2014, 2017). Total of 164 photographs were analyzed for the health condition of the mangrove community. Diameter of the mangrove stem was measured at the position of breast high, except some trees of mangrove Ceriops tagal were measured just below the branching system (at knee high). Stems diameter of mangrove at breast high of $16 \mathrm{~cm}$ and above were recorded as tree category. Mangrove with diameter of stem less than $16 \mathrm{~cm}$ and minimal height of $1.5 \mathrm{~m}$ were recorded as sapling category. Data of canopy height were also determined by measuring the elevation angle from the highest shoot to the distance of $10 \mathrm{~m}$ from the base canopy stem using a protractor. Data of mangrove communities in both tree and sapling categories were collected and analyzed based on the method provided by Dharmawan and Pramudji, 2014, 2017). Data for canopy covering percentage and diameter of mangrove stem were analyzed as the main parameter, reversed to Dharmawan \& Pramudji
(2014, 2017) using software ImageJ and a newly template spreadsheet. Furthermore, the health of the mangrove community was interpret based on the National Standard of Keputusan Menteri Lingkungan Hidup Nomor 201 tahun 2004 (Anonymous, 2004).

\section{Results and Discussion}

Total eight species from five genera, and four families of the mangrove community were fully identified (Table 2). Distribution of mangrove species on each station and transect is given in Table 3. The important values index of each mangrove species for tree, sapling, and all categories can be seen in Figure 1. For all categories, the dominance species in each transect were Ceriops tagal in SKTM02B, Rhizophora stylosa in SKTM03B, Rhizophora mucronata in SKTM04, and Rhizophora apiculata in SKTM04T.

Species composition of the mangrove community for the tree category in the Sekotong bay was less and/or more than mangrove communities in other areas of Indonesia. Number of mangrove species in Sekotong bay was lesss than what been reported by: Onrijal \& Kusmana, (2010); Lestari (2013); Eti et al. (2014); Handono et al. (2014); Akbar et al. (2015); Samsumarlin et al. (2015). The species number of mangrove in Sekotong bay however, much more compared to have been reported by: De Jesus (2012); Al Idrus et al. (2014); 
Japa, L et al. (2021). Jurnal Biologi Tropis, 21 (2): 441 - 447

DOI: http://dx.doi.org/10.29303/jbt.v21i2.2698

Sitompul et al. (2014); Hutabarat et al. (2015); Karnanda et al. (2016).

Table 2. List of Family, Genera, and Species Name of Mangrove Community in Sekotong Bay West Lombok

\begin{tabular}{lll}
\hline Families & Genera & Species \\
\hline Avicenniaceae & Avicennia & $\begin{array}{l}\text { Avicennia marina } \\
\text { A. officinelis }\end{array}$ \\
Combretaceae & Lumnitzera & $\begin{array}{l}\text { Lumnitzera ceramosa } \\
\text { Ceriops tagal }\end{array}$ \\
Rhizophoraceae & Ceriops & $\begin{array}{l}\text { Rhizophora apiculata } \\
\text { Rhizophora }\end{array}$ \\
& & $\begin{array}{l}\text { R. mucronata } \\
\text { R. stylosa }\end{array}$ \\
& & Sonneratia alba \\
\hline
\end{tabular}

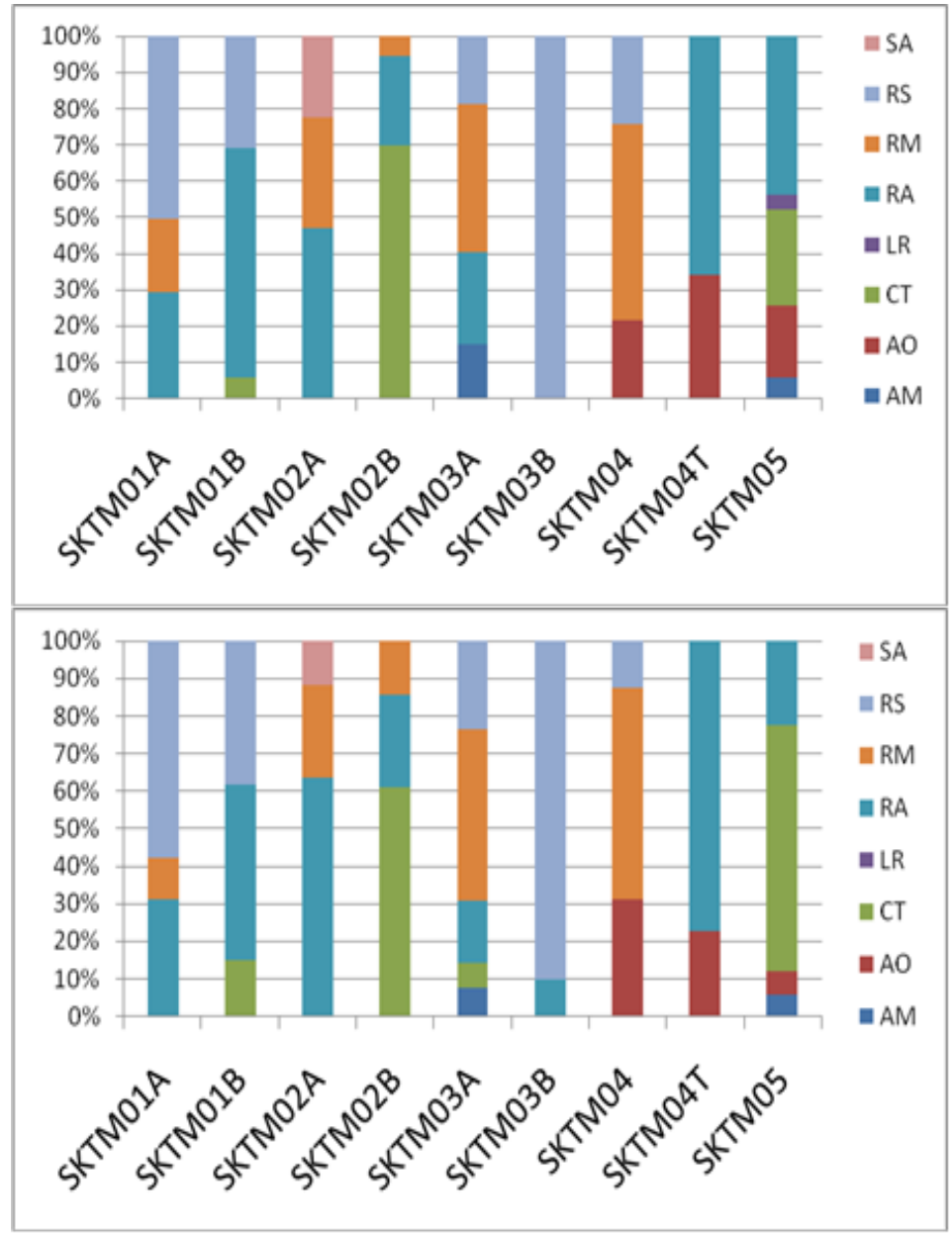




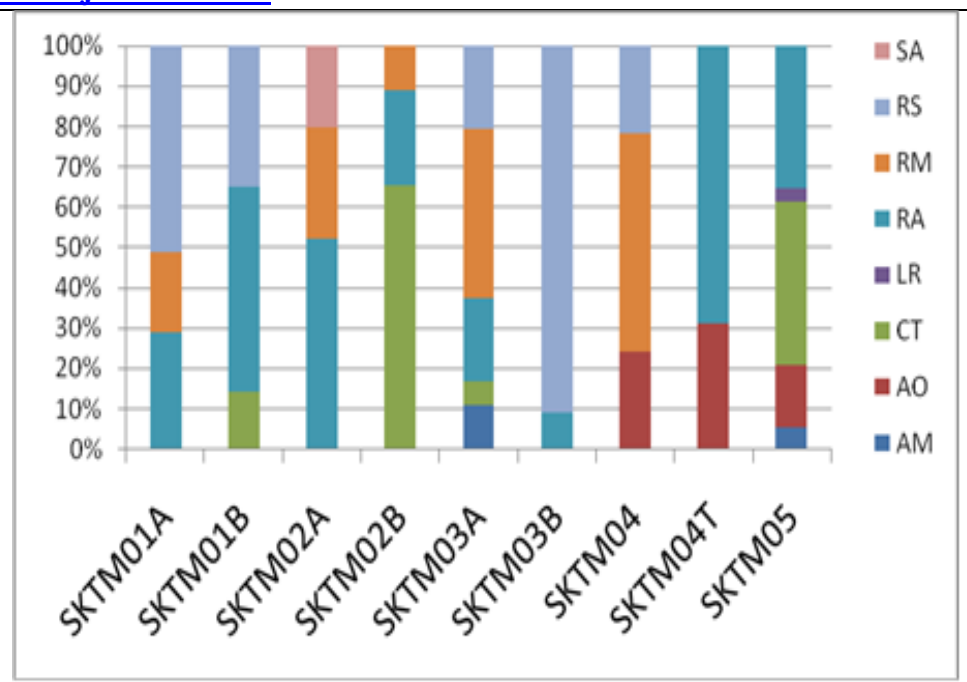

Figure 1. Proportion of the Impotence Values Index of Mangrove Species (A: Tree, B: Sapling, and C: All)

The highest and lowest density for mangrove tree category was recorded in trnasex SKTM02B and SKTM01B, 4467 ind./ha and 2400 ind./ha, respectively. Mangrove for sapling category, the highest density (9933 ind./ha) was recorded in transex SKTM03A, and the lowest density (1050 ind./ha) occurred in transex SKTM01B. Density comperation of mangrove tree and sapling category are provided in Figure 2. The average density of the mangrove sapling category is much higher than the density of the mangrove tree category. Density of sapling was much higher than the tree in transects SKTM03A, SKTM03B, and SKTM05. However, in transects SKTM01A, SKTM01B, SKTM04. density of sapling was lower than tree, and similar in transex SKTM04T.

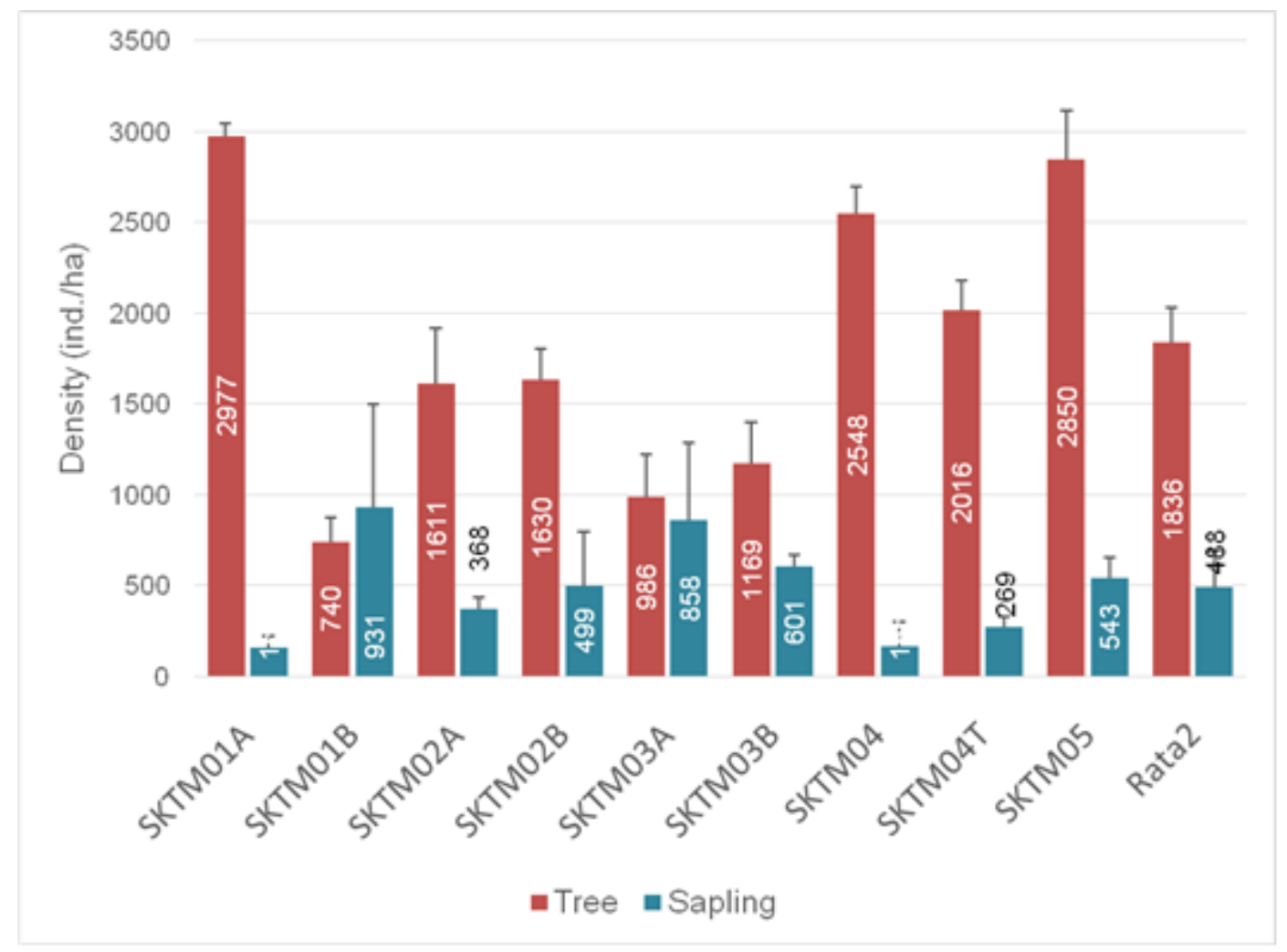


Figure 2. Density proportion of Mangrove Tree and Sapling Categories

Distribution and authority of transects numbers for each species of eight species of mangrove identified were various enough, in the range of one to seven (11-78\%) (Figure 3). Rhizophora apiculata was the only one species which has the highest percentage of area authority (78\%). The other seven species have the percentage of area authority less than $60 \%$, and two species with the lowest percentage of area authority $(11 \%)$ were Lumnitzera ceramosa and Sonneratia alba.

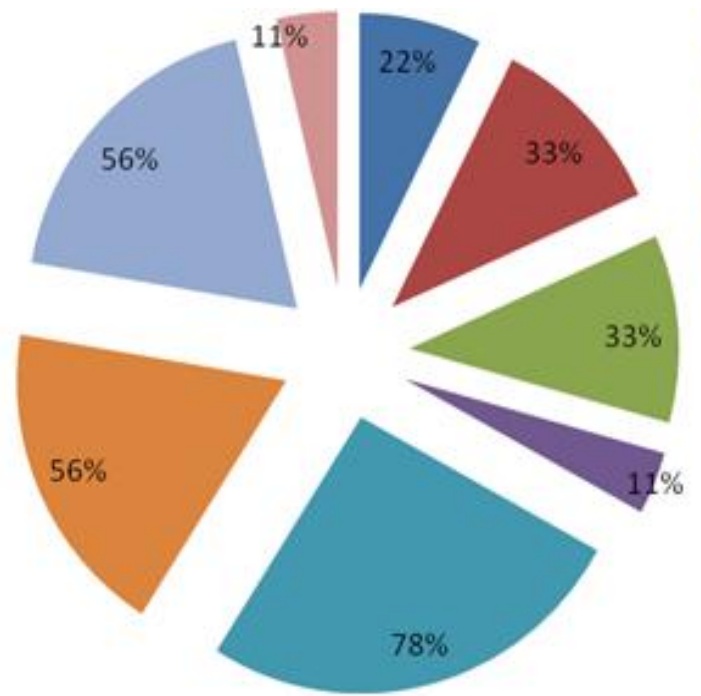

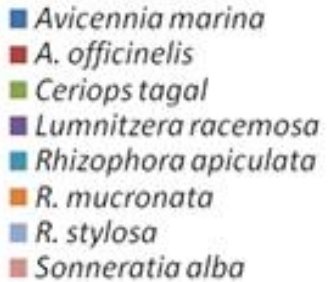

Avicennia marina

A. officinelis

- Ceriops tagal

- Lumnitzera racemosa

R. stylosa

In Sonneratia albo

Figure 3. Percentage authority Domination of each species of mangrove tree category to the number of transects

Table 3. Distribution of mangrove species at station and transects of sampling in the Sekotong Bay West Lombok in the year of 2019

\begin{tabular}{|c|c|c|c|c|c|c|c|c|c|}
\hline \multirow{3}{*}{ Name of Species } & \multicolumn{9}{|c|}{ Station and Transects } \\
\hline & \multicolumn{2}{|c|}{ SKTM 01 } & \multicolumn{2}{|c|}{ SKTM 02} & \multicolumn{2}{|c|}{ SKTM 03 } & \multirow{2}{*}{$\begin{array}{c}\text { SKTM } \\
04\end{array}$} & \multirow{2}{*}{$\begin{array}{c}\text { SKTM } \\
\text { 04T }\end{array}$} & \multirow{2}{*}{$\begin{array}{c}\text { SKTM } \\
05\end{array}$} \\
\hline & $\mathbf{A}$ & $\mathbf{B}$ & $\mathbf{A}$ & $\mathbf{B}$ & $\mathbf{A}$ & $\mathbf{B}$ & & & \\
\hline Avicennia marina & & & & & + & & & & + \\
\hline A. officinelis & & & & & & & + & + & + \\
\hline Ceriops tagal & & + & & + & & & & & + \\
\hline Lumnitzera raceramosa & & & & & & & & & + \\
\hline Rhizophora apiculata & + & + & + & + & + & & & + & + \\
\hline R. mucronata & + & & + & + & + & & + & & \\
\hline R. stylosa & + & + & & & + & + & + & & \\
\hline Sonneratia alba & & & + & & & & & & \\
\hline $\begin{array}{l}\text { Number of species in } \\
\text { transect }\end{array}$ & 3 & 3 & 3 & 3 & 4 & 1 & 3 & 2 & 5 \\
\hline Number of species in station & & & & & & & & 4 & 5 \\
\hline
\end{tabular}

The highest average high of mangrove tree category $(8,20 \pm 0,11 \mathrm{~m})$ occurred in transect SKTM04, and the lowest average high $(3,43 \pm 0,17 \mathrm{~m})$ was recorded in transect SKTM02B. The dominant of Ceriops tagal in SKTM02B can be the main reason for the lowest average high of mangrove tree category in this transect. The biggest stem diameter of mangrove tree category was $10,57 \mathrm{~cm}$ recorded at transect
SKTM04, and the smallest tree diameter $(6,10 \mathrm{~cm})$ recorded at transect $\mathrm{k}$ SKTM03A. The biggest diameter $(10,57 \mathrm{~cm})$ of mangrove tree in the Sekotong Bay is much smaller compared the diameter of naturally mangrove tree of the District of Wondama-Papua (Dharmawan \& Widyastuti, 2017). The high and diameter comparison of mangrove tree among transects are given in Figure 4. 


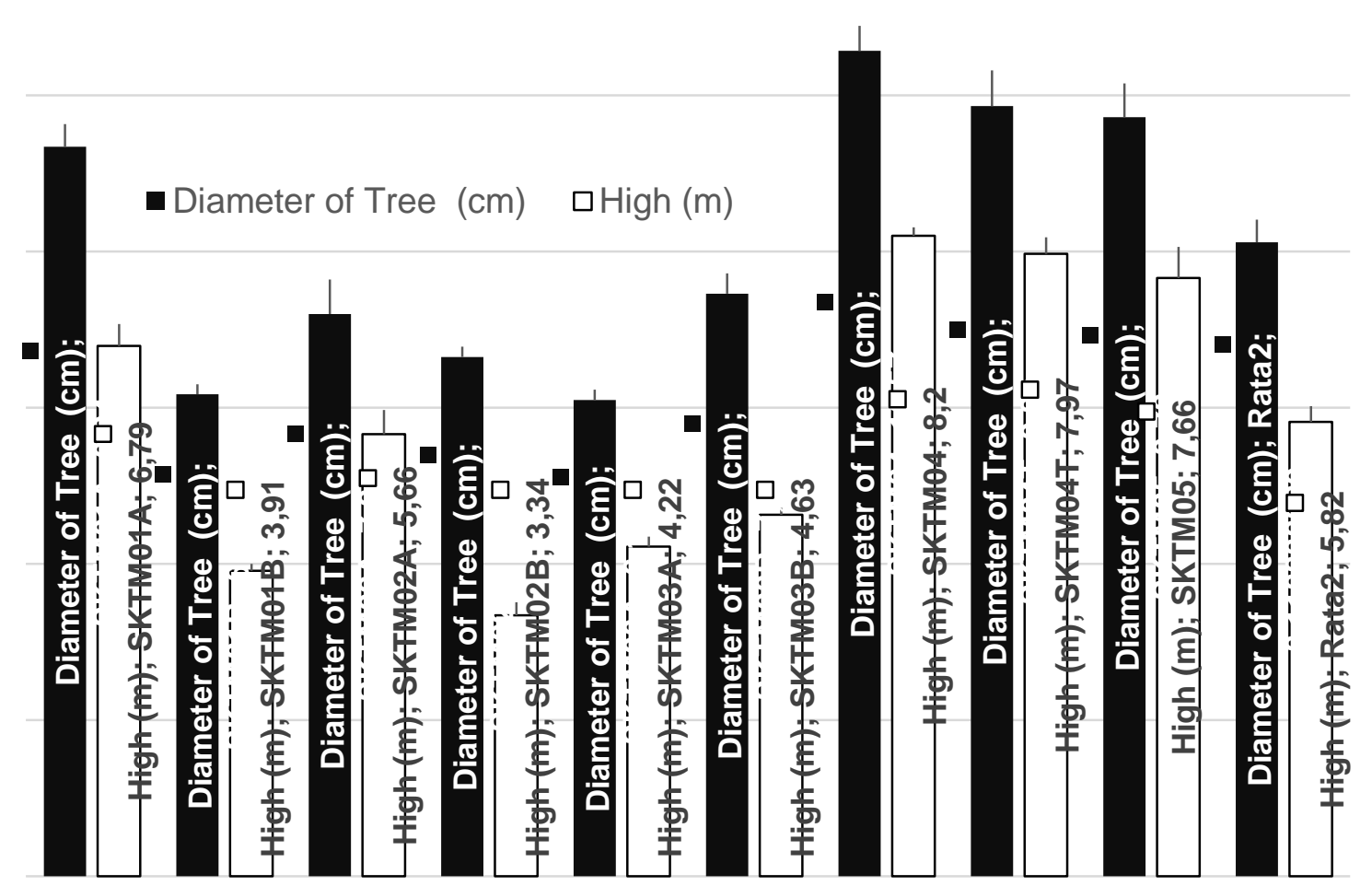

Figure 4. Portion of comparison of high and diameter of mangrove tree in among transects in the Sekotong Bay West Lombok

\section{Conclusion}

Community of mangrove forest in Sekotong Bay, West Lombok consists of eight species from five genera and four families. Based on the average density and percentage coverage of mangrove canopy, the community of mangrove was in good to very good categories. Rhizophora apiculata and Rhizophora stylosa were the two species of mangrove with the highest distribution reached $78 \%$ station and transects of research. Density of mangrove tree category almost always higher than sapling in all transects, except in transect SKTM01B. Three station with highest species diversity index were SKTM02, SKTM04, \& SKTM05.

\section{Acknowledgement}

Thanks to COREMAP-CTI-P2OLIPI for supporting funding. Thanks also goes to Dr. $\mathrm{H}$. Imam Bachtiar, M.Sc., as a team coordinator for preparing and providing all logistics, accommodation, transportation, consumption, and kindness giving all information always in early time. Supporting and friendly coordination and communication among the team members during preparation and in the field activities were also appreciated. Thanks so much also goes to all members of the mangrove team for hard work and funny communication during the field activity.

\section{References}

Akbar, N., A. Baksir, \& I. Tahir. (2015). Struktur komunitas ekosistem mangrove di kawasan pesisir Sigoli Kabupaten Halmahera Barat, Maluku Utara. Depik, 4(3):132-143.

Al Idrus, A., I G. Mertha, G. Hadiprayitno, \& M. L. Ilhamdi. (2014). Kekhasan Morfologi Spesies Mangrove di Gili Sulat. Jurnal Biologi Tropis. 14(2): 120-128.

Anonymous (2004). Keputusan Menteri Negara Lingkungan Hidup No. 201 tahun 2004, 
tentang Kriteria Baku \& Pedoman Penentuan Kerusakan Mangrove. Jakarta.

Backmann, R. (1994). Environmental Science. Australian Academy of Science. CamberraAustralia.

De Jesus, A. (2012). Kondisi ekosistim mangrove di sub district Liquisa Timor-Lesste. Depik, 1(3): 136-143.

Dharmawan, I.W.E. \& Pramudji (2014). Panduan Monitoring Status Kesehatan Komunitas Mangrove. CRITC COREMAP CTI LIPI. PT. Sarana Komunikasi Utama. Bogor.

Dharmawan, I.W.E., \& S. Pramudji (2017). Panduan Pemantauan Komunitas Mangrove. Edisi ke-2. Pusat Penelitian Oseanografi LIPI. Jakarta.

Dharmawan, I.W.E \& A. Widyastuti (2017). Pristine Mangrove Community in Wondama Gulf, West Papua, Indonesia. Marine Research in Indonesia, 42(2): 67-76.

Eti, R.N.A., A. Rustam, T.L. Kepel1, N. Sudirman, M. Astrid, A. Daulat, P. Mangindaan, H.L. Salim, \& A.A. Hutahaean (2014). Stok Karbon \& Struktur Komunitas Mangrove Sebagai Bblue Carbon Di Tanjung Lesung, Banten. Jurnal Segara. 10(2): 119-127.

Handono, N., R.H.R. Tanjung, \& L.I. Zebua (2014). Struktur vegetasi \& nilai ekonomi hutan mangrove Teluk Youtefa, Kota Jayapura, Papua. Jurnal Biologi Papua. 6(1): 1-11.

Hutabarat, Dinarta, Yunasfi, \& A. Muhtadi (2015). Kondisi ekologi mangrove di Pantai Putra Deli Desa Denai Kuala Kecamatan Pantai Labu Kabupaten Deli Serdang Provinsi Sumatera Utara. Aquacostmarine, 10(5): 141148.

Giri, C., E. Ochieng, L.L. Tieszen, Z. Zhu, A. Singh, T. Loveland, J. Masek, \& N. Duke. (2011). Status and Distribution of Mangrove Forests of the World Using Earth Observation Satelite
Data. Global Ecology and Biogeography, 20: 154-159.

Karnanda, M., Z. A. Muchlisin, \& M. A. Sarong. (2016). Struktur komunitas mangrove \& strategi pengelolaannya di Kabupaten Pidie, Province Aceh. Depik, 5(3): 112-127

Lestari, F. (2013). Identifikasi Kondisi Ekosistem Mangrove di Kawasan Pesisir Pulau Dompak Tanjungpinang. Agriplus, 23(02): 92-97.

Onrijal \& C. Kusmana (2010). Studi ekologi hutan mangrove di pantai timur sumatera utara. Biodiversitas, 9(1): 25-29.

Samsumarlin, I. Rachman, \& B. Toknok (2015). Studi zonasi vegetasi mangrove muara di desa umbele kecamatan bumi raya kabupaten morowali sulawesi tengah. Warta Rimba, 3(2): 148-154.

Saputra, R., Y.V. Jaya, \& F. Lestari (2016). Pemetaan Tingkat Kerentanan Habitat Mangrove Pulau Bintan. http://jurnal.umrah.ac.id/w.

Sitompul, O. S., Yunasfi, \& A. Muhtadi (2014). Kondisi ekologi mangrove di Pantai Bali Desa Mesjid Lama Kecamatan Talawi Kabupaten Batu Bara Provinsi Sumatera Utara. Jurnal Mitra Bahari, 8(2): 15-27.

Syafei, E.S. (1990). Pengantar Ekologi Tumbuhan. Institut Teknologi Bandung. Bandung. 